\title{
Caldithrix palaeochoryensis sp. nov., a thermophilic, anaerobic, chemo-organotrophic bacterium from a geothermally heated sediment, and emended description of the genus Caldithrix
}

Correspondence

Margarita L. Miroshnichenko alfamirr@mail.ru

\author{
Margarita L. Miroshnichenko, ${ }^{1}$ Tatyana V. Kolganova, ${ }^{2}$ Stefan Spring, ${ }^{3}$ \\ Nikolay Chernyh ${ }^{1}$ and Elizaveta A. Bonch-Osmolovskaya ${ }^{1}$ \\ ${ }^{1}$ Winogradsky Institute of Microbiology, Russian Academy of Sciences, Prospect 60-Letiya \\ Oktyabrya 7/2, 117312 Moscow, Russia \\ ${ }^{2}$ Bioengineering Center, Russian Academy of Sciences, Prospect 60-Letiya Oktyabrya 7/1, \\ 117312 Moscow, Russia \\ ${ }^{3}$ DSMZ - German Collection of Microorganisms and Cell Cultures, Inhoffenstraße 7b, 38124 \\ Braunschweig, Germany
}

\begin{abstract}
A novel thermophilic, strictly anaerobic, chemo-organotrophic bacterium, designated $\mathrm{MC}^{\top}$, was isolated from a geothermally heated sediment of a marine hydrothermal system at Palaeochory Bay, Milos, Greece. Cells of strain $\mathrm{MC}^{\top}$ were rods of variable length $(4-12 \mu \mathrm{m})$ and width $(0.2-$ $0.3 \mu \mathrm{m}$ ), occurring as single cells or forming large aggregates that were visible as flocs. Strain $\mathrm{MC}^{\top}$ grew optimally at $\mathrm{pH} 7.0$ and $60{ }^{\circ} \mathrm{C}$ and with $3 \%(\mathrm{w} / \mathrm{v}) \mathrm{NaCl}$. Strain $\mathrm{MC}^{\top}$ grew chemoorganoheterotrophically and fermented peptides and di- and polysaccharides in the presence of $0.1 \mathrm{~g}$ yeast extract $\mathrm{I}^{-1}$. The DNA $\mathrm{G}+\mathrm{C}$ content of strain $\mathrm{MC}^{\top}$ was $43.3 \mathrm{~mol} \%$. Phylogenetic analysis of the $16 \mathrm{~S}$ rRNA gene sequence placed strain $\mathrm{MC}^{\top}$ within the genus Caldithrix. However, strain $\mathrm{MC}^{\top}$ possessed certain phenotypic features that differentiated it from the type strain of the only species of the genus Caldithrix described to date. On the basis of phylogenetic and phenotypic characteristics, it is proposed that strain $\mathrm{MC}^{\top}$ represents a novel species, Caldithrix palaeochoryensis sp. nov. The type strain is $\mathrm{MC}^{\top}\left(=\mathrm{DSM} 21940^{\top}=\mathrm{VKM} \mathrm{B}^{-2536^{\top}}\right)$. In addition, an emended description of the genus Caldithrix is presented.
\end{abstract}

The genus Caldithrix represents a phylogenetically distinct lineage within the domain Bacteria that is comparable to phylum status (Miroshnichenko et al., 2003; Jumas-Bilak et al., 2009). At the time of writing, the genus contains only one species, Caldithrix abyssi, the type strain of which was isolated from a sample of a deep-sea hydrothermal chimney on the Mid-Atlantic Ridge (Miroshnichenko et al., 2003). In recent years, an increasing number of $16 \mathrm{~S}$ rRNA gene sequences have been deposited in public databases from environmental samples that are phylogenetically related to $C$. abyssi $\mathrm{LF}^{\mathrm{T}}{ }^{\mathrm{T}}$. The most similar sequences have been retrieved from the Lost City hydrothermal field in the Mid-Atlantic Ocean (GenBank accession no. FJ791936), the Juan de Fuca ridge in the Pacific Ocean (AY280423) and the Kazan mud volcano in the Mediterranean Sea (FJ712503). However, representatives of this phylogenetic group are apparently not restricted to hydrothermal vent fluids, as 16S rRNA gene sequences

The GenBank/EMBL/DDBJ accession number for the 16S rRNA gene sequence of strain $\mathrm{MC}^{\top}$ is FJ999729. sharing about $88 \%$ similarity with C. abyssi $\mathrm{LF} 13^{\mathrm{T}}$ have been retrieved from mangrove soil (GenBank accession no. DQ811936) and a sulfidic cave stream biofilm in Italy (DQ415763). One of the closest phylogenetic relatives to $C$. abyssi $\mathrm{LF}^{3}{ }^{\mathrm{T}}$ was detected by denaturing gradient gel electrophoresis of a bacterial community from a shallow hydrothermal vent of Palaeochory Bay (Sievert et al., 2000), located on the south-eastern coast of the Greek island of Milos in the geothermally active area of the South Aegean volcanic arc (Miroshnichenko et al., 2003). This sequence, band ML-5 (GenBank accession no. AF209001), shared $98.2 \% 16 \mathrm{~S}$ rRNA gene sequence similarity to C. abyssi $\mathrm{LF} 13^{\mathrm{T}}$ and represented a dominant fraction of the microbial population in this habitat (Sievert et al., 2000). In this paper, we describe a second species of the genus Caldithrix, isolated from a shallow volcanic area of Palaeochory Bay.

The sample site was located $10 \mathrm{~m}$ from the shore at about $1 \mathrm{~m}$ depth and $0.3-0.5 \mathrm{~m}$ in diameter and looked like a round white-yellow spot. The seabed at this location was covered with small pebbles, $0.2-0.5 \mathrm{~cm}$ in diameter, and 
sand. No signs of active venting or bacterial mats were observed. The temperature on the sediment surface at the centre of the site was $40{ }^{\circ} \mathrm{C}$, and there was a steep temperature gradient with depth: $5 \mathrm{~cm}$ below the sediment surface, the temperature was $30{ }^{\circ} \mathrm{C}$ higher. Samples of sediment with water were taken from $20-30 \mathrm{~mm}$ below the surface of the sediment, placed into sterile Falcon tubes and transported to the laboratory at an ambient temperature, where they were stored at $4{ }^{\circ} \mathrm{C}$.

For the enrichment of anaerobic, chemo-organotrophic, thermophilic bacteria, anaerobically prepared BM medium (Miroshnichenko et al., 2003) was supplemented with $\left(1^{-1}\right)$ $1 \mathrm{~g}$ yeast extract, $1 \mathrm{~g}$ acetate, $1 \mathrm{~g} \mathrm{Na}_{2} \mathrm{~S}_{2} \mathrm{O}_{3}$ and $1 \mathrm{~g} \mathrm{NaNO}_{3}$ and the medium was adjusted to $\mathrm{pH} 7.0$ with $6 \mathrm{M} \mathrm{HCl}$. A subsample of the sediment $\left(1 \mathrm{~cm}^{3}\right)$ was inoculated into $10 \mathrm{ml} \mathrm{BM}$ medium in $15 \mathrm{ml}$ Hungate tubes with $\mathrm{N}_{2}$ as the gas phase and incubated at $55^{\circ} \mathrm{C}$. After 5 days of incubation, the growth of two morphologically diverse micro-organisms was observed: oval motile cells were dominant and thin rods were present as a minor component. Colonies were obtained on BM agar (1.5\%) using the agar-shake method. After 7 days of incubation at $55^{\circ} \mathrm{C}$, the highest dilution showed spherical colonies of two types. Both types of colonies were about $1.5 \mathrm{~mm}$ in diameter, but differed in colour, being either white or grey. Individual colonies were transferred into liquid BM medium and, after 3 days of incubation at $55{ }^{\circ} \mathrm{C}$, developed into two morphologically different cultures: oval-shaped cells, designated $\mathrm{HM}$, and rod-shaped cells, designated $\mathrm{MC}^{\mathrm{T}}$. $16 \mathrm{~S}$ rRNA gene sequence analysis showed that strain HM showed $100 \%$ similarity to Desulfacinum hydrothermale MT- $96^{\mathrm{T}}$, which was isolated previously from Palaeochory Bay (Sievert \& Kuever, 1999). Strain $\mathrm{MC}^{\mathrm{T}}$ was found to be affiliated to the genus Caldithrix and was characterized in detail.

After demonstrating that growth of strain $\mathrm{MC}^{\mathrm{T}}$ did not depend on the presence of acetate, nitrate or thiosulfate, we used BM medium supplemented with only $1 \mathrm{~g}$ yeast extract $1^{-1}$ for growth experiments or, for growth with di- and polysaccharides, $0.1 \mathrm{~g}$ yeast extract $\mathrm{l}^{-1}$. Morphological and physiological studies were performed as described previously (Miroshnichenko et al., 2003). Electron microscopy (Bonch-Osmolovskaya et al., 1990) indicated that cells of strain $\mathrm{MC}^{\mathrm{T}}$ were thin rods of variable length $(4-12 \mu \mathrm{m})$ and width $(0.2-0.3 \mu \mathrm{m})$ and had one polar flagellum (Fig. 1). Cells of strain $\mathrm{MC}^{\mathrm{T}}$ were motile during early exponential growth phase. Formation of spherical empty bodies, which is typical of $C$. abyssi, was also observed for strain $\mathrm{MC}^{\mathrm{T}}$. In liquid culture, cells of strain $\mathrm{MC}^{\mathrm{T}}$ aggregated into flocs.

Strain $\mathrm{MC}^{\mathrm{T}}$ was an obligate anaerobe that only grew on $\mathrm{BM}$ medium when the content of $\mathrm{Na}_{2} \mathrm{~S} .9 \mathrm{H}_{2} \mathrm{O}$ was reduced to $0.5 \mathrm{~g} \mathrm{l}^{-1}$. The optimal growth temperature of strain $\mathrm{MC}^{\mathrm{T}}$ was $60{ }^{\circ} \mathrm{C}$. No growth was observed above 65 or below $40{ }^{\circ} \mathrm{C}$. The $\mathrm{pH}$ range for growth was $\mathrm{pH}$ 6.2-7.5 (optimum $\mathrm{pH}$ 7.0). Growth was obtained with $0.5-6.5 \%(\mathrm{w} / \mathrm{v}) \mathrm{NaCl}$

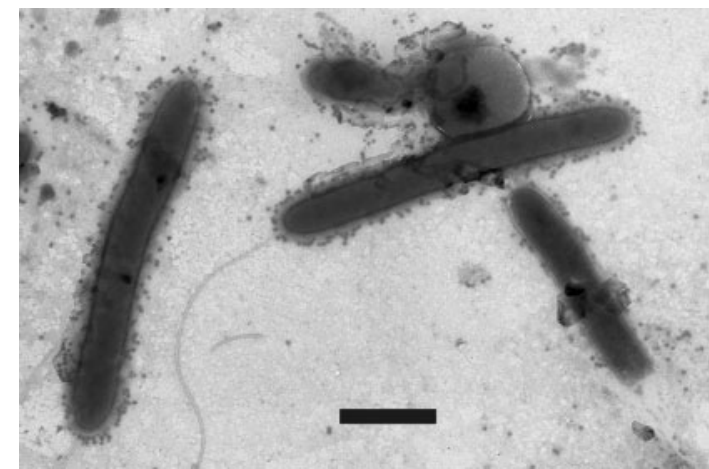

Fig. 1. Electron micrograph of whole cells of strain $\mathrm{MC}^{\top}$ at stationary growth phase. Bar, $0.5 \mu \mathrm{m}$.

(optimum $3.0 \% \mathrm{NaCl}$ ). The generation time of strain $\mathrm{MC}^{\mathrm{T}}$ was 60 min under optimal conditions.

In the presence of $0.1 \mathrm{~g}$ yeast extract $\mathrm{l}^{-1}$, strain $\mathrm{MC}^{\mathrm{T}}$ grew chemo-organotrophically by fermentation of variety of proteinaceous substrates and carbohydrates. The following growth substrates were used: yeast extract, beef extract, biotrypticase and peptone (all at $2 \mathrm{~g} \mathrm{l}^{-1}$ ) and maltose, sucrose, glucose, fructose, arabinose, galactose and pyruvate (all at $20 \mathrm{mM}$ ). Weak growth of strain $\mathrm{MC}^{\mathrm{T}}$ with starch $\left(2 \mathrm{~g} \mathrm{l}^{-1}\right)$ and agarose $\left(1 \mathrm{~g} \mathrm{l}^{-1}\right)$ was observed. The following substrates were tested but not utilized: fumarate, succinate, trehalose, lactose, pectin, microcrystalline cellulose and xylan. Molecular hydrogen, lactate, acetate, butyrate, ethanol and a trace amount of propanol were produced during growth with yeast extract as a substrate. Strain $M C^{\mathrm{T}}$ was not able to grow by the oxidation of hydrogen using nitrate, sulfur or thiosulfate as electron acceptors. The $\mathrm{G}+\mathrm{C}$ content of the DNA of strain $\mathrm{MC}^{\mathrm{T}}$, determined as described previously (Miroshnichenko et al., 2003), was $43.3 \mathrm{~mol} \%$.

Analysis of $16 \mathrm{~S}$ rRNA gene sequences was performed according to methods described elsewhere (Miroshnichenko et al., 2008). Briefly, calculations were based on an alignment of almost-complete 16S rRNA gene sequences from the sILVA database (release 95; Pruesse et al., 2007) and included sequences from type strains representing the distantly related phylum Deferribacteres for comparison. A maximumparsimony tree was constructed using programs included in the ARB software package (Ludwig et al., 2004) and a maximum-likelihood tree was constructed with the RaxML program. The phylogenetic analysis (Fig. 2) placed strain $\mathrm{MC}^{\mathrm{T}}$ in the genus Caldithrix with $96.4 \%$ similarity to the only cultured representative, C. abyssi $\mathrm{LF} 13^{\mathrm{T}}$. Thus, according to the currently accepted concept of bacterial taxonomy (Rosselló-Mora \& Amann, 2001), strain $\mathrm{MC}^{\mathrm{T}}$ represents a novel species within the genus Caldithrix. Based on 16S rRNA gene similarity, representatives of the genus Caldithrix were most closely related to members of the genus Deferribacter. However, the similarities were very low $(80.7-81.5 \%)$ and do 

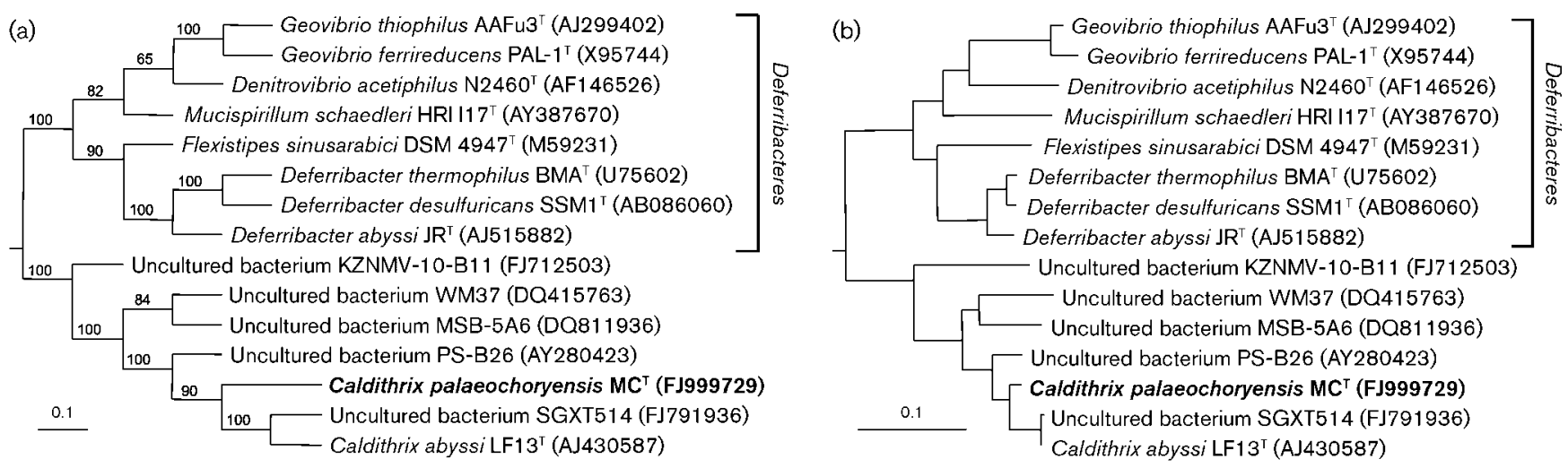

Fig. 2. Maximum-parsimony (a) and maximum-likelihood (b) trees, based on $16 \mathrm{~S}$ rRNA gene sequences, showing the affiliation of strain $\mathrm{MC}^{\top}$ with the genus Caldithrix. Percentages at nodes are bootstrap values based on 1000 replications. The sequence of Escherichia coli ATCC $11775^{\top}$ (GenBank accession no. X80725) was used as an outgroup (not shown). Bars, $10 \%$ estimated sequence divergence.

not justify the affiliation of the two genera in the same phylogenetic group. In addition, the affiliation of strains of the genus Caldithrix with the phylum Deferribacteres was not supported by bootstrap values.

Strain $\mathrm{MC}^{\mathrm{T}}$ shared some features with C. abyssi DSM $13497^{\mathrm{T}}$. Indeed, cells of both organisms were thin rods of variable length and often formed spherical protrusion bodies. However, in contrast to C. abyssi DSM $13497^{\mathrm{T}}$, cells of strain $\mathrm{MC}^{\mathrm{T}}$ were motile by use of one polar flagellum. Both strains were moderate thermophiles and obligate anaerobes capable of chemo-organotrophic growth. However, metabolically, C. abyssi DSM $13497^{\mathrm{T}}$ and strain $\mathrm{MC}^{\mathrm{T}}$ were distinctly different (Table 1). In contrast to C. abyssi DSM $13497^{\mathrm{T}}$, which is a facultative chemolithotroph that oxidizes

Table 1. Comparative characteristics of strain $\mathrm{MC}^{\top}$ and $\mathrm{C}$. abyssi DSM $13497^{\top}$

Data were taken from this study and Miroshnichenko et al. (2003). Cells of both strains are rods.

\begin{tabular}{|lcc|}
\hline Characteristic & MC & $\begin{array}{c}\text { C. } \text { abyssi } \\
\text { DSM } \mathbf{~ 1 3 4 9 7}^{\mathbf{T}}\end{array}$ \\
\hline Cell size $(\mu \mathrm{m})$ & $0.2-0.3 \times 4-12$ & $0.2-0.35 \times 4-20$ \\
Flagellation & + & - \\
Lithotrophic growth with $\mathrm{H}_{2}$ & - & + \\
Respiration & - & + \\
Fermentation of & + & - \\
$\quad$ carbohydrates & & $\mathrm{H}_{2}, \mathrm{~A}, \mathrm{P}$ \\
Fermentation products & $\mathrm{H}_{2}, \mathrm{~L}, \mathrm{~A}, \mathrm{~B}, \mathrm{EtOH}$, \\
from yeast extract & $\mathrm{PrOH}$ & \\
DNA G+C content $(\mathrm{mol} \%)$ & 43.3 & 42.5 \\
& & \\
\hline
\end{tabular}

${ }^{\star}$ A, Acetate; B, butyrate; EtOH, ethanol; L, lactate; PrOH, propanol; $\mathrm{P}$, propionate. molecular hydrogen and acetate in the presence of nitrate, strain $\mathrm{MC}^{\mathrm{T}}$ showed no signs of the ability to respire anaerobically with these electron donors. With respect to chemo-organotrophic growth, strain $\mathrm{MC}^{\mathrm{T}}$ was an obligately fermentative chemo-organotroph that could grow on di- and polysaccharides as well as proteinaceous substrates, in contrast to C. abyssi DSM $13497^{\mathrm{T}}$, which has a spectrum of organic substrates limited to peptides and pyruvate.

Based on the significant phylogenetic and phenotypic differentiation from C. abyssi DSM $13497^{\mathrm{T}}$, we propose that strain $\mathrm{MC}^{\mathrm{T}}$ should be assigned to a novel species within the genus Caldithrix, for which we propose the name Caldithrix palaeochoryensis sp. nov.

\section{Emended description of the genus Caldithrix}

The description of the genus Caldithrix is as given by Miroshnichenko et al. (2003) with the following amendments. May be able to ferment di- and polysaccharides. The ability to respire anaerobically with molecular hydrogen or acetate as the electron donor and nitrate as the electron acceptor is variable. The DNA G $+\mathrm{C}$ content is $42.5-43.3 \mathrm{~mol} \%$.

\section{Description of Caldithrix palaeochoryensis sp. nov.}

Caldithrix palaeochoryensis (pa.lae.o.cho.ry.en'sis. N.L. fem. adj. palaeochoryensis pertaining to Palaeochory Bay in Greece, where the type strain was isolated).

Cells are thin motile rods, $0.2-0.3 \mu \mathrm{m}$ in diameter and 4$12 \mu \mathrm{m}$ long. Obligate anaerobe. Growth occurs between 40 and $65{ }^{\circ} \mathrm{C}$ (optimum $60{ }^{\circ} \mathrm{C}$ ) and at $\mathrm{pH}$ 6.2-7.5 (optimum $\mathrm{pH}$ 7.0). Obligate chemo-organotroph and ferments peptides and di- and polysaccharides. The DNA G $+\mathrm{C}$ content of the type strain is $43.3 \mathrm{~mol} \%$. 
The type strain, $\mathrm{MC}^{\mathrm{T}}\left(=\mathrm{DSM} 21940^{\mathrm{T}}=\mathrm{VKM} \mathrm{B}-2536^{\mathrm{T}}\right)$, was isolated from a shallow hydrothermal vent of Palaeochory Bay, Milos, Greece.

\section{Acknowledgements}

We are grateful to Dr Konstantinos Kormas and Ioanna Akoumianaki for their help in organizing the expedition to the island of Milos. This work was supported by the Russian Academy of Sciences programmes 'Molecular and Cell Biology' and 'Origin and Evolution of the Biosphere'.

\section{References}

Bonch-Osmolovskaya, E. A., Sokolova, T. G., Kostrikina, N. A. \& Zavarzin, G. A. (1990). Desulfurella acetivorans gen. nov. and sp. nov. - a new thermophilic sulfur-reducing eubacterium. Arch Microbiol 153, 151-155.

Jumas-Bilak, E., Roudière, L. \& Marchandin, H. (2009). Description of 'Synergistetes' phyl. nov. and emended description of the phylum 'Deferribacteres' and of the family Syntrophomonadaceae, phylum 'Firmicutes'. Int J Syst Evol Microbiol 59, 1028-1035.

Ludwig, W., Strunk, O., Westram, R., Richter, L., Meier, H., Yadhukumar, Buchner, A., Lai, T., Steppi, S. \& other authors (2004). ARB: a software environment for sequence data. Nucleic Acids Res 32, 1363-1371.
Miroshnichenko, M. L., Kostrikina, N. A., Chernyh, N. A., Pimenov, N. V., Tourova, T. P., Antipov, A. N., Spring, S., Stackebrandt, E. \& BonchOsmolovskaya, E. A. (2003). Caldithrix abyssi gen. nov., sp. nov., a nitrate-reducing, thermophilic, anaerobic bacterium isolated from a Mid-Atlantic Ridge hydrothermal vent, represents a novel bacterial lineage. Int J Syst Evol Microbiol 53, 323-329.

Miroshnichenko, M. L., Tourova, T. P., Kolganova, T. V., Kostrikina, N. A., Chernyh, N. \& Bonch-Osmolovskaya, E. A. (2008). Ammonifex thiophilus sp. nov., a hyperthermophilic anaerobic bacterium from a Kamchatka hot spring. Int J Syst Evol Microbiol 58, 2935-2938.

Pruesse, E., Quast, C., Knittel, K., Fuchs, B., Ludwig, W., Peplies, J. \& Glöckner, F. O. (2007). SILVA: a comprehensive online resource for quality checked and aligned ribosomal RNA sequence data compatible with ARB. Nucleic Acids Res 35, 7188-7196.

Rosselló-Mora, R. \& Amann, R. (2001). The species concept for prokaryotes. FEMS Microbiol Rev 25, 39-67.

Sievert, S. M. \& Kuever, J. (1999). Desulfacinum hydrothermale sp. nov., a thermophilic, sulfate-reducing bacterium from geothermally heated sediments near Milos Island (Greece). Int J Syst Evol Microbiol 50, 1239-1246.

Sievert, S. M., Kuever, J. \& Muyzer, G. (2000). Identification of $16 \mathrm{~S}$ ribosomal DNA-defined bacterial populations at a shallow submarine hydrothermal vent near Milos Island (Greece). Appl Environ Microbiol 66, 3102-3109. 